\title{
"What alerts, alters": Hacking the Narratives of Cultural Memory with Rankine, Eady, and Philip
}

\author{
Jennifer Shook
}

Poet Harryette Mullen connects the long literary tradition of reference and recycling with more recent versions of "remix" culture in her Recyclopedia, arguing that "poetry... remakes and renews words and images, ideas, transforming surplus cultural information into something unexpected," even "salvages and finds imaginative uses for knowledge," a generative re-creation that finds not only new art but also new horizons for the human (Mullen vii). Writers have long found power within historical material, and long leaned upon their audiences' collective knowledge of the past in order to enter and amend cultural memory. ${ }^{1}$

As information theory joins literary and cultural criticism, new vocabularies emerge that can expand our understandings of poetry's aesthetic and ethical potentials for meeting the past and for constructing the future. Looking at poetic projects as "hacks" in the dataset of cultural memory changes our understanding of narrative to a technology that can proliferate alternatives, rather than ossifying a dominant paradigm. If we visualize the ideas recycled through poetry as information flow, then a "hack" can serve as a productive metaphor for generative intervention. Traditionally, "hacking" refers to interference in computer networks. McKenzie Wark, however, recuperates the word from its teen basement computer geek prankster image in A Hacker Manifesto. In Wark's hands, "hack" becomes an action applicable to any creative act, metaphorized as tapping into the flow of power or diverting restricted information into avenues of greater access. ${ }^{2}$ While production merely copies, a hack differentiates (Wark paragraph 160). For Wark "to hack is to release the virtual from the actual" (Wark paragraph 74). Wark's interest lies in the value of hacking itself, but I propose a more targeted use of the idea: to hack is to break apart collective memory's seemingly fixed narratives, allowing multiple 


\section{IJCS}

stories to emerge into actual life.

Claudia Rankine, Cornelius Eady, and M. NourbeSe Philip further this expansion of social memory, and their formally demanding hacks may be usefully read with N. Katherine Hayles' formulations of database and narrative. For Hayles the technologies of narrative and database/dataset function symbiotically; applying her vocabulary allows a vision of cultural memory as a malleable dataset holding exponentially more possible narratives than normally visible.

Such notions of information offer a structure for reading authors who insist that the past is never truly past, never complete, and never contained in one telling. Strategically applying the computer programming term "database," or more accurately here "dataset," allows a continuation of Eric Havelock's and Rachel Blau DuPlessis' interventions in the archives of memory and culture. After all, a dataset "is not a stable archive but a constantly shifting set of relationships" (KochnarLindgren 136). Artworks that call attention to their own construction, as Rankine's, Eady's, and Philip's do, also point to the data assembly of culture itself. Hacks must expose that "what is represented as being real is always partial, limited, perhaps even false" (Wark paragraph 74). So while narrative masquerades as fixed-the only possible story to be told, the only possible arrangement of parts - in reality the pieces of a dataset may be organized and read in any number of ways, telling any number of stories and voicing any number of perspectives and characters. Hayles' materiality attention also counters Wark's virtuality obsession, so that both may be marshaled in the reading of poetry and performance, theoretical incursions upon time with real-world resonances.

Claudia Rankine's Don't Let Me Be Lonely: An American Lyric pries open the seemingly fixed narrative of American memory through the staging of a constructed subjectivity. Cornelius Eady's drama Brutal Imagination invites history's hidden specters into public view, directly confronting the fissures exposed by Rankine's (anti)-lyric. M. NourbeSe Philip's Zong! conjures new ancestors from a wordbank originally used to silence/erase marginalized humans. These three hacks exemplify the kind of poesis and the kind of criticism that can find alternate futures within the collective memory, first making visible the invisible process of mythologizing, then reconfiguring the seemingly rigid dataset in order to release liberatory possibility. Additionally, hacking as metaphor provides an entry point into reading formally complex, challenging texts such as these.

Although Wark champions hack for hack's sake, Rita Raley identifies "hacktivists" who disrupt the systems of data power for political and aesthetic purposes, such as the Yes Men's "Amnesty 2000" campaign to "hijack" the presidential website (georgewbush.com). On their gwbush.com "Bush" offered to release Texas prisoners held on drug charges, since he himself admitted to using drugs, and since nonviolent drug-related offenses increasingly dominate the prison system (Raley 7). ${ }^{3}$ While a standard hack may interfere with the data flowing through a particular channel, the Yes Men redirect data onto a new track, in many cases to allow alternate or expanded information. Raley also notes that hack and 
freedom of flow may exclude one another, for example in denial-of-service attacks, such as SWARM's (South West Action to Resist the Minutemen) FloodNet "sit-in" meant to "interfere with and slow down" the servers of California and Arizona Minutemen by sending repeated search requests for "files like Justice, Freedom, and the names of those who have died crossing the border," obviously "files not found" on these anti-immigration websites (Raley 41). The hacktivists discussed in Raley's Tactical Media differ in their valuations of information flow, but most demonstrate a political, educational, and often transformative purpose beyond the act of hacking itself. They seek "not to impose a definitive countermessage but to provoke and to reveal, to defamiliarize and critique" in service of "a new way of seeing, understanding, and (in the best-case scenario) interacting with a given system" (Raley 7). This wide-angle perspective suggests that the vocabulary of information allows new vistas for the cultural work of literary criticism in the information age.

New media's embrace of transitory interventions offers hope for literary works to disrupt dominating narratives without re-freezing the system into a new "countermessage." In an earlier moment, Rachel Blau DuPlessis called for a "Revisionary Mythopoesis," a feminist shift in perspective away from the usual angle. DuPlessis' early work identifies the archive of myth as burden and treasure trove, a series of condensed symbols to be deployed but also a heavy weight holding back suppressed versions. Those whose information paths branch outside the dominant culture flow face both opposition and opportunity when confronting myth and social memory. Outside the normal paths of the cultural story, women and writers of color (for instance) feel non-linear automatically, because the line did not include them in its construction. ${ }^{4}$ As Paul Connerton explains of social memory:

what is lacking in the life histories of those who belong to subordinate groups is precisely those terms of reference that conduce to and reinforce this sense of a linear trajectory, a sequential narrative shape: above all, in relation to the past, the notion of legitimating origins, and in relation to the future, the sense of an accumulation in power or money or influence. (Connerton 19)

On the one hand, the stories pushed out by the narrative order struggle to break in, resulting at times in a breaking of form itself, as in Rankine's playful disordering of the lyric and lyric self in Don't Let Me Be Lonely. On the other hand, myth and memory can function as a dataset, ready to be remined in infinite recombinatory forms. Connerton traces numerous reworkings of Greek myth, for instance. ${ }^{5}$ For Connerton, rather than the "inertia of something already presignified and formalized," myth "constitutes something more like a reservoir of meanings," containing "a range of potential meanings significantly in excess of their use and function in any particular arrangement. ... a surplus of meaning - a surplus which can be realized in variable interpretive arrangements" (Connerton 56-57). Using similar language, Hayles complicates even narrative's restrictive nature, suggesting 


\section{IJCS}

with Alan Liu that narrative can approach "data pour" or "transcendence," dancing in the realm of the unknown or incomprehensible while "databases in themselves can speak only that which can be explicitly spoken" (Hayles "Symbionts" 1605). While it may be helpful to think of a set, dominant narrative as that which submerges complications from view, Hayles demonstrates that narrative and dataset can actually work together to surface the excluded and expand the network of voices.

DuPlessis explores this tenuous partnership in the vocabulary of myth in Writing Beyond the Ending, a phrase she glosses as "the transgressive invention of narrative strategies, strategies that express critical dissent from the dominant narrative" (DuPlessis 5). DuPlessis critiques myth in Barthesian terms, as myth has erased the traces of its own making and so holds tremendous power as "truth." DuPlessis' main project lies in the ability of women to author a counter-story, to see the myth from another perspective. Invoking A Room of One's Own, she unconsciously demonstrates the way that technology has long served to illustrate our understandings of information flow, as Woolf's modernist metaphors of railways so match the metaphors of data switching tracks:

...I feel as one feels on a switchback railway when the car, instead of sinking, as one has been led to expect, swerves up again. Mary is tampering with the expected sequence. First she broke the sentence; now she has broken the sequence.... whenever I was about to feel the usual things in the usual places, about love, about death, the annoying creature twitched me away, as if the important point were just a little further on. (DuPlessis 31)

Yet in their mythological hacks, Rankine, Eady, and Philip take the intervention further, not merely switching the track to tell a counter-story, but breaking open the fixed structures to allow virtually any combination of data to emerge. In DuPlessis' terms, they rupture the system precisely by engaging its data, finding in myth "a maximum tension with and maximum seduction by dominant stories" (DuPlessis 106). While DuPlessis does not quite envision this radical potential, she does provide a useful term for the kind of awareness it requires: from W.E.B. DuBois she borrows the term "double-consciousness" to express the ability to see both the existing narrative and other possible narratives within the dataset (DuPlessis 42). Gwendolyn Brooks, for instance, insists that a Black writer might view even trees differently, thinking of a tree both as a tree but also "of how his ancestors have been lynched thereon" (DuPlessis 115). Even the seemingly simplest, apolitical, personal data may be arranged into various narrative contexts.

If valued for its own sake outside an ethical framework, the continual repurposing of the hack could perpetuate endlessly, producing no social change, merely endless countermessages, still assuming with DuPlessis' mythopoesis that a truth exists and can be transferred among tellers. Wark would argue that these variants accrue and add up, but the best hacks go further to "reconfigur[e] the 
geometry of attention" (Retallack 10). By highlighting the construction of narratives as arrangements of data, hacks like those explored here empower readers to directly question and create from the cultural archive. As Claudia Rankine puts it, "What alerts, alters." Even subtle shifts in flow can literally create/make happen, can "releas[e] the latent capacities" of information, as information is the "potential of potential" (Wark paragraph 128) ${ }^{6}$. In that case, reading literature/myth/history as code, as rewritable/rearrangeable, leads to new creation and the release of unseen potential.

To hack, then, could be more than just a trendy term to get theorists like Wark gigs speaking at Google. Building upon Hayles' engagement of dataset and narrative as a means of understanding medial ecology, hacking may be a means to change the world, as "Inscribing consequential fictions, writing machines reach through the inscriptions they write and that write them to re-define what it means to write, to read, and to be human" (Hayles Machines 131). Hayles, of course, did not invent database aesthetics, nor is the applicability of database theorizing limited to twentyfirst century narratives. Jay David Bolter and Richard Grusin trace hypermediacy back at least to seventeenth century perspective drawing (Bolter 12). Over forty years ago Eric A. Havelock described Homeric epics in database terms, noting that even Plato called Homer a "tribal encyclopedia" (though his argument has more to do with memory storage methods). Havelock breaks Homer's narrative into modular parts whose remix potential allows for artistic improvisation. The artistry shows mainly in the poet's ability to combine effect and report, "bringing the tale into continual contact with the general social apparatus" (Havelock 90). Through Havelock's lens, Homer begins to resemble a video remixer, rearranging and recording without passion precisely because of his commitment to his society. In this model, narrative functions to control the "apparatus" as well as to create effect. Through control, the narrative makes its own work invisible, as if it represents the only available combination of data.

To release other potential narratives from the dataset, the hacker must first make visible both the repressive structure and the submerged data. ${ }^{7}$ Using the language of the computer age, one might say that DuPlessis' perspective shift rearranges the modular pieces of the dataset, as one rearranges pieces in a doll's house, making a new story to replace the old. Claudia Rankine, then, turns the lyric against its own tradition; like Anne Sexton's ax in a sea of ice, Rankine pries open the dollhouse walls. Subtitling Don't Let Me Be Lonely as An American Lyric, Claudia Rankine engages the genre expectations of lyric, the usual contract between author and reader to share emotional personal truth through legible cultural symbols. In Rankine's hands, the lyric (and the "self") becomes a lever that can pry open assumptions to expose not only the silences beneath, but also the construction of the meaningmaking culture system itself. ${ }^{8}$ Like many other poets, Rankine resists closure, "communicating the fact that the poem is a process without resolution," as she explained in an interview with jubilat (Flescher and Caspar). Rankine plays with the fictional construction of self, using first-person perspective in a way that complicates 


\section{IJCS}

the "I" rather than embracing it as transparent or exploiting it as a completely distanced mask. (Because Rankine's speaker both is and is not the author, I will refer to the speaker as "Claudia" while distinguishing the author as "Rankine.") The pieces of Lonely circulate almost entirely in the "I" for the first quarter of the book, even situating news stories and the opinions of Cornel West with Claudia's responses. The first piece lacking first-person connection depicts a girl on a roof, watching clouds and shouting a Milosz poem, mistaken for a suicide jumper by the people below (Rankine 35-36). This seemingly unrelated poem unsettles the reader's relationship to the speaker, appearing to dislocate Claudia's control or presence in the narrative. Alternately, we might believe the girl on the roof is also Claudia, or must relate to her in some way. Already, we are looking for connections, but Rankine is "not interested in creating anything that contributes to the fiction of wholeness" (Flescher and Caspar). The "public imagination" lives through "I"s, and Rankine uses other "I"s to counter and flesh out this imagination. She models this process pedagogically through Claudia's meeting with her editor, her plan for an article on the liver:

I understand that what she wants is an explanation of the mysterious connections that exist between an author and her text. If I am present in a subject position what responsibility do I have to the content, to the truth value, of the words themselves? Is 'I' even me or am 'I' a gearshift to get from one sentence to the next? Should I say we? Is the voice not various if I take responsibility for it? What does my subject mean to me? (Rankine 54)

Rankine exposes that "I" can be merely a gearshift; in admitting "I, or we, it hardly matters," she calls attention to the construction of subjectivity and of the relationship between reader and text (Rankine 67). Forced to confront the falsehood of Claudia's unified self, readers then must question the "truths" they purport to "know" about "real" people, for example Black men brutalized by racist violence-_public" figures whose lives and deaths affect Claudia's "private" world.

Claudia pulls focus in and out of public awareness, pointing into her own bedroom where she looks for socks and stops to watch television, and out into the world where the televised events unfold. Rankine tells jubilat that Lonely began as an effort to recover James Byrd from the "gesture of closure" that "erase[d]" him behind the punishment of the three men who dragged him behind a truck to his death in 1998 (Flescher and Caspar). Rankine's desire "to bring him back visually" led her to resurrect other lost figures from recent history, and then to expand into "a conversation set up through the text's relation to the image" (Flescher and Caspar). ${ }^{9}$ Yet true to her play with "lyric," moments of public record in television screens and magazine references reinterpolate themselves into the personal. While Prozac is the subject of research and commercials, it speaks to an individual's emotions. One of several faux-scientific drug-marketing-style drawings first accompanies the 
discussion between Claudia and her editor about her writing on the liver. The image replaces the liver with the United States as the largest organ in the human body, as if the political self physically marks a person's guts (Rankine 54).

Next, two more subjects of racism ghost the television screens ${ }^{10}$ : Abner Louima (a Haitian immigrant brutalized by police in 1997) and Amadou Diallo (an unarmed West African immigrant shot forty-one times by police in 1999); through these pieces, Rankine builds a constellation that nonetheless resists narrative, because like the forty-one shots, these shards of history "never add up, never become plural, and will not stay in the past" (Rankine 57). Claudia experiences this kind of loss as "physical" yet "It is not something an 'I' discusses socially" (Rankine 57). ${ }^{11}$ The next section turns loss back to the individual level, when Claudia's "sister's children and her husband died in a car crash" and then "a friend's mother dies when she is on her way home from her father's funeral," suggesting a definition of loneliness as "what we can't do for each other" (Rankine 61-63). After seeing her grieving friend, who "seems fine," Claudia reveals her sister to be a "construct," a "character" who "feels erased," although she tells this fictional sister (through her notes) she will do "anything" for her. This new crack in Claudia's fictional wholeness, in the lyric trustworthiness of the woman who had revealed her sadness and her cold toes, makes suspect all new figures who enter the poem, such as "A husband" who wakes to ask how she slept (Rankine 63). Rankine confesses that "It's important that people don't think I had a sister whose husband and children died in a car crash," yet the fictional sister reappears later, "distracted" (Flescher and Caspar; Rankine 77). Rankine wants the images and the notes at the end of the text to "take away the 'literal truth' authority from the text ... destabilize the text further... make the book messier," but because the notes appear at the end and are not signaled by numbers within the poems, they hide from first-time readers (Flescher and Caspar).

As a result, Claudia's imaginary sister "is being made to perform a life [Claudia doesn't] want to live," both because Rankine controls her, and because within the poems she suffers through the aftermath of tragedy (Rankine 77). Again connecting the note apparatus and media presence to personal relationships, Claudia considers telling her sister about a Harper's piece on insurance adjusters as a way of bridging her learned knowledge with her sister's lived knowledge, but decides not to, since she doesn't "want to risk generalizing her experience" (Rankine 77). Does assigning the brunt of loss to a fictional sister generalize the loss of figures like James Byrd? Or does lyric specificity recuperate nameless, silent loss, allowing to readers the kind of connection Claudia feels to Louima on her television? The sorting of life details for the imaginary dead children's imaginary insurance adjuster parallels this construction of character, since "each [child's] activity is a sign" suggesting "worth," and thus suggesting the start of a narrative that will never be completed because the lives have ended (Rankine 78). Connerton compares this psychoanalytic construction of a life to the act of remembering, of "forming meaningful narrative sequences. In the name of a particular narrative commitment, an attempt is being made to integrate isolated or alien phenomena into a single unified process" 


\section{IJCS}

(Connerton 26). Rankine has already connected the idea of worth to linearity and narrative when Claudia recalls that her mother wanted her to have a "readable life" to make her pregnancy and labor worthwhile (Rankine 40). Again, Claudia's personal narrative mirrors Rankine's larger social narrative of what DuPlessis aptly names "interpretation masked as representation" (DuPlessis 106). Pushed and pulled between intimate invitations and intimacy fractured, readers must recognize the interpretive assumptions at play in their understandings of story characters, including figures in the news.

Meanwhile, Claudia continues to remediate, in Hayles' terms, blurring the boundaries between television screens, books, prescription labels, billboards, and computers. Media pervades her world, and thus her readers' experience, since she "leave[s] the television on all the time" but only catches bits as she goes in and out of the room (Rankine 15). ${ }^{12}$ Making choices about one's character looks remarkably like choosing a data path: "There is a button on the remote control called FAV. You can program your favorite channels. Don't like the world you live in, choose one closer to the world you live in. ... This is what is great about America-anyone can make these kinds of choices" (Rankine 24). Rankine exploits lists so ubiquitous as to be amusing (as in drug side effects) (Rankine 73). Adrift in the information of her world, sifting various data streams in an effort to construct meaning (and self), Claudia keeps looking for authority or at least an apparatus of control. These efforts repeatedly fail, however, just as the drugs fail to repress sorrowful memory from the American character. Even Claudia knows that "all the narrative control in the world does not offer ... insight" into, for example, a professional mourner (Rankine 122). Rankine bitterly quips at the choices that make a life when she lists such "Kodak moments, full of individuation... on our way to our personal best" as dilemmas like "To have a new iMac or not to have it? To eTrade or not to eTrade?" (Rankine 91). Immediately following, however, a particularly efficient textimage ${ }^{13}$ from the United States Post Office asks "What should make me suspect a piece of mail?...What should I do with a suspicious package?" making Claudia "begin to watch herself closely." She begins to realize that "how [she] was alive," how she thought she "was a fearless person" was a "product" constructed of marketing and ownership, and again here the I melts into a larger belonging, as she says "The America that I am is washing her hands" (Rankine 92-3). The textimage of the post office warning performs multiple functions: it places the readers inside Claudia's world, seeing what she sees; its corporeality spills into readers' world and incorporates them. It also allows a found list to engage with Claudia's personal lists, affecting her; and it places readers who remember this warning or similar instructions back into their mindset from that time. ${ }^{14}$

Such tactics produce Claudia as what Hayles calls a "remediated narrator, a literary invention foregrounding a proliferation of inscription technologies that evacuate consciousness as the source of production and recover in its place a mediated subjectivity that cannot be conceived of as an independent entity," forcing readers to engage in complicated technologies and thus confront their own 
"consciousness" as "fused with technologies of inscription" (Hayles Machines 117). Not surprisingly, Claudia even tries an internet search; when perplexed by a friend's comment after reading a novel, "what woman hasn't been raped," Claudia begins to wonder about statistics, and ponders "Perhaps this is the kind of thing I could find out on Google." Rankine juxtaposes this "perhaps" with a remediation, the image of an empty Google search field. Claudia realizes before googling that "maybe "what woman hasn't been raped' could be another way of saying 'this is the most miserable of my life" (a mysterious phrase that has gathered meaning during the course of the book through repetition including visual "affordances," to use Hayles' term, textimages that form part of the narrative). However the notes reveal that Rankine did in fact perform the "I'm Feeling Lucky" search on "keywords 'rape' and 'statistics' on November 17, 2003 at 8:22p.m." resulting in the information that approximately 1 in 6 women subject to rape or attempted rape (Rankine 72, 145). Google, particularly in its "I'm Feeling Lucky" mode, provides a lucid illustration of the way a narrative may emerge triumphant from the chaos of entropic data. As dataset, it can only return contents present on the internet; in privileging some data over others, it narrows the flow of information.

Inside the world of the book, readers rely upon Rankine to return the most useful and exciting bits. Yet the contrast of typing "rape" and clicking "feeling lucky" suggests the pitfalls of surrendering control. Indeed, Rankine's hypermediacy makes use of technological possibilities to "challeng[e]" readers to "appreciate the integration of text and image" as Bolter and Grusin say of medieval illuminated or rubricated large capital initial letters (Bolter 12). Hayles argues (counter to those who fear the dataset as the end of human story) that narrative will never disappear, since inference, temporality, and causality make it an "essential technology for human beings, who can arguably be defined as meaning-seeking animals" (Hayles "Symbionts" 1606). Rankine finds productive tension in fighting her audience's desire to construct readable narrative, even as she depicts this tension as already part of human life, a source of wonder and of sorrow for Claudia.

As hypermediacy calls attention to itself, it "reminds us of our desire for immediacy" (Bolter 24). Claudia and Rankine encourage their readers "to see the other as one sees the self...by offering a word" (Rankine 120). The artist's job is to envision, and Rankine envisions a "handshake" (Rankine 130). The word she offers (on a billboard) is "Here," and though she offers it across an abyss she herself has taken pains to point out, through her hack she shows where a bridge may be built. Her "here," her ending of the book with "in the presence of" (and no object to finish the sentence) offers an empty container waiting to be filled.

Cornelius Eady follows Rankine in her search for "a mode that can accommodate without pretending to transcend, that manages to stay in the mess and continue an exploration of thought in the imagination" (Flescher and Caspar). If Rankine levers open the box, Eady shakes up the pieces in it, digging deep into the "white imagination" to find its "vision of the black man" in popular culture and in fictionalized history (Eady Poems back cover). Like Rankine, Eady assembles a 


\section{IJCS}

character from pieces he finds in the cultural dataset - only in Eady's case he gives voice to a character already "invented," the "black man in a knit cap" Susan Smith claimed kidnapped her two sons to deflect from her infanticide. Eady adapted the two-character drama Brutal Imagination from his own poem cycle with the same name. In the play, Eady names the black man "Mr. Zero"; 15 he embodies the cipher that holds a world. In both the play and the poem cycle, this man's first speech finds his own moment of conception, or "How I Got Born": "When called, I come./My job is to get things done" (Eady 5). DuPlessis' and DuBois' double consciousness applies to a long theatrical tradition; performance theorists from Zeami to Brecht have expected actors to have consciousness of themselves both within and outside the confines of their role and for audiences to know that what they see on stage both is and is not literally happening. Theatre straddles boundaries between the imagined and the "real," calling attention to virtuality itself. When Banquo's ghost walks onstage, regardless of whether Macbeth imagines him or not, the audience witnesses a presence. Likewise, Mr. Zero takes over Susan's car, but Eady suspends two data paths throughout the play, balancing Susan's lie with its actual real-world reverberations.

Eady defines the characters' relationship in the play differently than in the poems: in the latter, the black man "lives, against his will, in a kind of eternal halflife... available to do the dirty work of our subconscious," to tell "the truth, even if he knows no one can ever really hear him" in order "that a reader might be able to explore and examine our own assumptions — what they're made of, and how they affect the world - without getting one's back up." The play, meanwhile, creates "a duet" between historical record and imagined criminal, "between ... a woman who needs someone to carry a horrible burden for her," and a character "whom she invents to carry it. (But, as she is soon to discover, for a price, and only so far)" (Eady 3). The play also delves further into the historical archive, language from local papers serving as historical reminders, "narrative glue, as well as color and background" (Eady 3). Realizing that Susan Smith would be soon if not already forgotten, he clearly understands that even forgotten she falls into the world of archetypes and assumptions about what she must be like, as does her Mr. Zero. In this "duet" the characters display meta-knowledge of themselves as characters, and in so doing can like Rankine expose the way that humans bend perception and information to tell their stories. In this play about how history gets made, and how it gets read and how art participates in that making and reading, Mr. Zero parallels Claudia's remediated nature, yet insists upon the consequences of his invention, the virus of society's need for him.

Structurally, the play mirrors its origin as "persona poems" - again, many of the pieces could be rearranged, since they do not follow a linear chain of events but rather reflect the kind of inevitability DuPlessis sees in myth and Rankine sees in movies (Eady 3). Not only does the audience know that Susan Smith drove her sons into the lake in 1994, but even within the world of the play their deaths have already happened, while Susan and Mr. Zero ride the bubble of days before that realization 
comes to light. As a specter, Mr. Zero can travel both forward and backward in time, linking his current guise to the history of his role in racial blame. He accrues reality as a composite police sketch, "flicker[s] from TV to TV ... pour[s] from lip to lip... crackle[s] from cell phones and short wave" (Eady 14). He sits with Charles Stuart in a hospital in Boston in 1989 after Stuart "killed his pregnant wife and shot himself in a scheme to collect insurance money," telling "police the assailant was a young black male" (Eady 22). Smith "knew [she] could get further with this if [she] said a black man did it" (Eady 21). Her lie worked for as long as it did because "we knew exactly who she was describing," the "scariest face you could think of" (Eady 44, 12). Zero and Susan both voice racist data from the cultural archive, how even to children

Someone pointed

A finger

In the wrong direction, the wrong side of the tracks, chocolate-town, coonville

And said:

All they do

Is fuck and drink. (Eady 13)

Susan's audience knew the man she was describing because they had seen him countless times before, on television.

Eady goes beyond merely calling out commercial image-makers; he implicates his audience in the image-making by conjuring up ghosts of the race-obsessed past as Zero morphs into " $a$ cast of characters who lie buried in [Susan's] subconscious": Buckwheat, Aunt Jemima, Stagolee, Steppin-Fetchit, and Uncle Tom (Eady 24). Connerton outlines a dataset of "the past ... as a vast collection of images, all styles of the past being potentially open to the play of random, often humorous, allusion" (Connerton 62). In the waiting room of the cultural memory's dataset stereotypes watch Mr. Zero on stage and wait for Eady to invite them to play. "Play" might feel misplaced here, but like Brecht Eady uses humor to set a trap to show his audience their complicity, part of Brecht's campaign to "think feelingly and feel thinkingly," a thread taken up by Rankine (through Cesar Vallejo) in Claudia's desire to "thin[k] as if trying to weep" (Rankine 89). As with Raley's tactical media artists, play serves as a lever to disrupt power, "discover[ing]" "holes in existent technologies" and then "projecting potential change through those holes" (Raley 12). Like the tension Rankine finds in her audience's desire to construct readable lives, Eady deploys a Brechtian advantage in his audience's discomfort with minstrel performance. Eady's archetypes come mostly from the comic tradition but arrive with deadly serious points, as Mr. Zero becomes the little rascal Buckwheat, whose family predicts his white friends will desert him when he's grown, that his "hair will become/Hoo-doo," that he will become "a childlike man who lives in a shack" 


\section{IJCS}

(Eady 25). From a relatively innocuous television character, Eady moves back into more recognizably dangerous times as Zero performs minstrel characters. Steppin Fetchit "finds flyers of the composite sketch" of Zero made from Susan's description, then "throws them up in the air" while "Shouting 'No! No!... 'It's raining men!"' (Eady 26). Minstrel shows caricatured black performance and black persons into mere representations; as Steppin Fetchit admits,

There's only an image left that they

Name you after, toothy, slow,

Worthy of a quick kick in the pants.

I used to have bones, I'd tell him.

But it was a story that

Rubbed out my human walk. (Eady 26$)^{16}$

The flip side of this clown's coin critically mimics what Susan desires, since "Maybe she thinks she's got the real deal,/The man in the song, with the slick hair/And the oiled pistol, the walking blues" (Eady 27). Stagolee shows Susan what a dangerous game she's playing, the game that arms the anger of the (mis)represented, and he "forces Susan to the ground" as he cries,

I'm a bad man, a chipped gold tooth,

Fresh blood in a Doberman's mouth.

She thinks they stride through hell.

She ought to try the world that made me.” (Eady 27)

Even Uncle Tom strides the boards "in Heaven"; he knows that his "name is mud," but "denied the/Power to hate" his author:

I watch another black man pour from a

White woman's head. I fear

He'll live the way I did, a brute,

A flimsy ghost of an idea. Both

Of us groomed to go only so far. (Eady 24)

The limited nature of these narratives makes them easy to use, but still, the inability to line up data in a coherent and consistent manner, to make of the details a readable life, ultimately caught Susan Smith in her lie. List-like data comparisons of "What Is Known About The Abductor" line up what Zero has "not done" with what people expect or report (Eady 31). As Zero warns, as Charles Stuart had already learned, "We do quick, but sloppy work" (Eady 22). Susan falters in her story's details, as Zero goes on "Putting on and taking off ski caps,/Curling and relaxing my hair,/Trying hard to become sense" (Eady 23). DuPlessis anticipates Susan's success 
and failure in her reading of Brooks' "A Bronzeville Mother Loiters in Mississippi. Meanwhile, a Mississippi Mother Burns Bacon.” Brooks sets up Emmett Till as a villain (as did his lynchers); as DuPlessis notes, "The wife had a script to damn the youth that was complete, dominant, and enthralling. However, that story comes completely undone" (DuPlessis 113). DuPlessis parallels other "social strategies, 'to refuse to accept the assumption that the role is inevitable,' or to achieve a change of consciousness, might correspond to the active rupture with a narrative order, the tactic of delegitimation" linked to telling one's own story rather than accepting others' versions (DuPlessis 112). Meanwhile, the repetition of Zero's recyclical return echoes eternal truths only to refuse them.

Again, in the double of virtual consciousness, Zero lives two lives. On the one hand, "Since her fear is my blood/And her need part mythical,/Everything she says about me is true" (Eady 7). Yet by definition he embodies the instability of narrative: "that number after the decimal that keeps/Stuttering, won't resolve" (Eady poems 41). In DuPlessis' words, Eady's modifications offer "another kind of story, with the definition of what has finally 'happened' never completed, always capable of modification, always doubling and questioning itself' (DuPlessis 121). The repetition of performance, amplified by Zero's repetition in history, echoes and enhances Hayles' iteration processes and Rankine's use of fiction to stage the "real," reminding the audience that "Memory is not passive repetition of the stabilized hasbeen, but is rather a generative force that shapes the events it re-counts" (KochnarLindgren 82). As Brutal Imagination breaks the narrative into its code, it puts history's data back into flow for further use. ${ }^{17}$ As Eady's play questions what is "real," he both employs and critiques the solidity of historical and legal record, hacking the empirical, verifiable, documented "real."

Where Rankine finds space for the lost of history and mass media within her TV screens, and Eady embodies marginal characters of entertainment and history onstage, M. NourbeSe Philip conjures the voices of murdered and unnamed ancestors in the poems of Zong! Philip gives an author credit to ("As told to the author by") Setaey Adamu Boateng, and her dustjacket author bio ends with the sentence "Setaey Adamu Boateng is the voice of the ancestors revealing the submerged stories of all who were on board the Zong." This sentence does not appear in Philip's bio at the back of the book, nor does the name appear anywhere else in the text, though in the "Notanda" Philip does mention at least two moments where text serendipitously happens (she includes a printer malfunction as the section named "Ebora"-glossed as "underwater spirits"-and later a piece of paper wafts down to her attention), and in the "Acknowledgements" she thanks "the Ancestors for bestowing the responsibility of this work on me," ending with "Àse," defined in her glossary of Yoruba words as "may it manifest" (Philip xii, 184). The word manifest resonates with potential meanings: a ship's inventory, a destiny, a clarity, a surface reading, a coming to attention/sight. Philip's method of "mining" words to find other words within them (and "smaller individual poems to be found") mirrors the culling of the law for precedents and the sifting of the ocean for bodies, as well 


\section{IJCS}

as the searching of a dataset (Philip 192).

Philip certainly plays with medial ecology in the flow of spiritual medium, though rather than simply transcribing, she has been tasked with both finding and organizing the items that will "untell" the "story that cannot be told." Where Rankine and Eady invoke bitter wit in their loud mourning, Philip tolls a long slow bell for the 150 or more Africans drowned off the slave ship Zong to claim insurance money during a trouble-plagued voyage in $1781 .{ }^{18}$ Using the appellate opinion of Gregson v. Gilbert, the only extant historical document related to the murderous voyage and its ensuing legal battle, she "excavate[s]" the voices and stories of the slaves and the crew using only a wordbank built from the legal text, finding the story "locked within this text" (Philip 191). The resulting poems bear traces of the wordbank's erasure methodology in their words and word bits scattered amid white space like the "flotsam" of a wreck (Philip 195). Philip includes her glossaries as appendices, broken into lists of cargo, lists of women waiting at home for their sailor loves, lists of food, lists of body parts, and "words and phrases overheard on board the Zong," divided into languages including Dutch, French, Latin, Spanish, Shona, and Yoruba (Philip 183-185). While these glossaries allow a construction of meaning through the various arrangements in the poems, Philip also breaks them past meaning, into fragments of mere sound, data resisting narrative. This linguistic breakage mirrors the breaking of silence, but also the breaking of humanity and human body parts, the breaking of sense. In its insistent and resistant mourning, Philip's “wake" surpasses even the tensions of Rankine's and Eady's doubleconsciousness (Philip 202). ${ }^{19}$

Like SWARM's file requests for absent ephemera, Philip plays with the idea that words hold more than meets the eye, more even than the word may literally contain, becoming a "negation of negation" (Raley 41). This excess, this data pour, expresses both Philip's frustration at what cannot be found (the names, for instance, of the murdered Africans), but also gestures toward the "ineffable" presence Hayles finds in narrative (Hayles "Symbionts" 1605). While Philip cannot locate "the just in ration," she repeatedly demonstrates methods to find the "ruse in insure," even the "zen in frenzy" (Philip 40, 80, 66). This repeated pattern uses list functions to depict meaningless attempts at order, but also to evoke ritual incantation, as if her hack conjures a spirit who cannot be named but may appear if the right space is prepared. Beginning with the impossibility of speech in the face of silenced tragedy, an incoherent "w W W W a wa" barely building to "water," Philip moves from the realm of should-not and how-could ("was/should/was not/should be") to an attempt to stand in the shoes of history, conjuring the voices of crew and slaves in letters home, in passing phrases, in hallucinatory rambling, and in the echoes of the waves (Philip 38). ${ }^{20}$ Of course the letters home may have no way to reach their destination, a fact mentioned by crew member and underscored by a slave who requests a letter written to his wife and then eats it before leaping to his death. Although the Zong and some of its people (even perhaps some of its captured Africans) eventually made it to shore, legal gestures of closure and the intervening 
centuries of inattention lose the ancestors in the ocean depths and in the spirit whispers. To recover them from the wasteland of data, Philip hacks open the closures of history, law, and racism by literally hacking apart the law's language.

Wark's positing of "to hack" as "to abstract... to produce the plane upon which different things may enter into relation," speaks directly to Philip's project to "Break and Enter the text to release its antimeaning," to make space and make flow in language as a way of finding potential in life (Philip 200). She "produce[s] kinds of relations, and relations of relations, into which things may enter" (Wark paragraph 83). For example, a king reads a paper documenting that "he o/wn s negro es man $y$ man y man y negroes..." (Philip 133). Here the reader's double consciousness must balance the relation between "many many negroes" owned and "negro es man y man y man" or "negro is man and man and man," one of the many moments when cultures and languages collaborate to interrogate systems of power in Zong!

Like Rankine, Philip uses the genre of lists and records to foreground humanity against constraining structures. Several of the poems provide "multiple reading paths," across or down or even diagonally on the page (Hayles Linkmap). For example, reading left-to-right, "Zong! \#14" declares "the truth is/the ship sailed/.../ the loss arose/ the negroes is," while reading down the columns reveals "the truth is/the negroes is" (Philip 24). ${ }^{21}$ As Hayles points out in her "media-specific analysis" reading other literary texts through a medial lens, Philip accomplishes this modular feat in a purely literary way, with typographical specificity of "spatial writing" and even of fonts that look handwritten interrupting and speaking to other typefaces as polyvocality takes over the text. Philip first ghosts her "exhumed" or "exaquaed" slave names along the bottom of pages like footnotes, but the poems end with a reverse triangle of "handwritten" names, mimicking eighteenth-century printing practice. As a visual poetry, the words present the reader with multiple possible arrangements, which disappear when read aloud. ${ }^{22}$ This ambiguity presents readers with an interface that requires interactivity; their choices make them coauthor the text as they read. As a result, Philip both empowers and implicates her readers in the violence of the resurrection, the narrative flesh growing on data's bones. ${ }^{23}$

Like Eady and Rankine, Philip sometimes lulls the reader with song, seducing with a fiction that then pulls the reader up short with a conclusion such as "negroes exist/for throwing" (Philip 34). She also paints breathless transcendence in some of her material constructions, as "in/the between of day/a sea of negroes/drowned/live/in the thirst/ for/otherwise" (Philip 35-36).

Can language make meaning, make actual material change? Or is it relegated to "dicta," which Philip defines as "comments that are pertinent to a case but do not have direct bearing on the outcome" (Philip 183)? Hayles describes the power of such arrangement of parts as modular in the sense that they can be reordered, but observes that because dataset and narrative work as symbionts, the mere arrangement reweights and redefines those parts: "Sensitively dependent on the order in which information is revealed, narrative cannot in general accommodate the addition of new elements without, in effect, telling a different story" (Hayles 


\section{IJCS}

"Symbionts" 1607). Philip demonstrates this power to remake the world through arrangement in the first piece of "Dicta" (a subsection within "Os," the very bones she uses to "exaqua" her ancestors); from "owners without/africa/seas/insurers/islands/perils" she proceeds to "africa without/perils/seas/insurers/islands/owners," first disenfranchising the system of slavery and then reinventing a safe homeland (Philip 49). Poetry has long enjoyed the power of words to perform different functions according to their context and formal arrangement, ${ }^{24}$ and for Philip this malleability suggests a potential pedagogy for reading Zong!, though in many ways the text undoes any methods readers may try upon it. In a sense, the fluid melting between voices, languages, characters, and words performs an interrogation of whether "lives own their facts," returning to Rankine's complications of the self in cultural memory (Philip 39). As Saint Augustine reminds in Philip's epigraphs, "The past is ever present" (Philip 126). Yet Philip must recover the past's information from its dissolution as well as eternally fight the impulse toward recapturing it in an equally rigid counter-narrative. She fights forces that confine ("the absolute/of rule") as well as forces that silence ("the absolute/of water") (Philip 39). The impulse to make manifest follows Rankine's belief that "what alerts/alters" and Eady's desire to bring racism to light by physically confronting a racist myth.

Philip also concentrates on the body, similar to the bodies made and troubled by Eady and Rankine. Her section titles reflect physical remains and elemental residues: "Os" (bone), "Sal" (salt), "Ventus" (wind), and "Ferrum" (iron), as well as the elusive (non)sense of the law, "Ratio" (reason). Even Ruth, the woman most frequently addressed by the ghostly crew, derives her name from a fragmenting of "truth": "suppose then t/ruth a rose/over/\&/ over/with you/she f/alls falling" (Philip 62). Words break apart in swimming constellations as "oh" and "es" and "o" "s" crystallize into "os," Latin for bone and one of the section names (Philip 63). Meanwhile, the ship itself found its name in a misnaming; originally the Zorg (Dutch for "care"), a mistake in repainting made it into its historically preserved self. Philip works with the mistakes that come to her, as Eady works with the characters that live in his audience's heads.

All three writers animate and reanimate characters from the data of collective memory. When faced with the solid flow of information usually dominated by the singular narrative, those outside the dominant structure hack. Applying Wark's claims to reading literature, we can see that "hackers teach [readers] how to hack"; in other words, writers like Rankine, Eady, and Philip not only make the virtual actual, through their models they set in motion ongoing hacks by other writers and readers (Wark paragraph 86). These hacks refuse to accept poetry and performance as sterile intellectual exercise or entertainment. ${ }^{25}$ Instead, they show the power of art's encoding to unveil and remake code, breaking language and looping the visual in new narratives on the highly condensed field of memory. "Every hack," insists Wark, "is an expression of the inexhaustible multiplicity of the future, of virtuality" (Wark paragraph 78). Perhaps energy has been displaced in mourning how few read 
a book of poems or see a play. Raley makes a strong case for the power of even transitory tactical maneuvers, "spontaneous eruption, the momentary evasion of protocological control structures, the creation of temporary autonomous zones, that surely play their part in making possible the opening for political transformations" (Raley 27). In fact if the hacks sought new permanent narratives or failed to call attention to their own making, they would merely create new essentialisms. Raley agrees with Bourriaud as to the value of "learning to inhabit the world in a better way, instead of trying to construct it based on a preconceived idea of historical evolution... to actually be ways of living and models of acting within the existing real" (Raley 27). Hacks find and manifest the "surplus of possibility" in a dataset. As Adrienne Rich puts it, "the imagination - the capacity to feel, see what we aren't supposed to feel and see, find expressive forms where we're meant to shut up - has meant survival and resistance, for poets and numberless others" (Rich 92-3). Even when the archive is as large and as burdened as cultural memory, hacks actuate new narratives in the "inexhaustible domain of what is real but not actual, what is not but may become" (Wark paragraph 74). Art intervenes in the seemingly inalterable landscape of information, but seeing culture as information opens up room for resistance.

\section{Notes}

${ }^{1}$ I am following Marita Sturken's lead in preferring the term "cultural memory" to "social" or "collective" for its inclusion of the "self-consciousness" inherent in the workings of culture. Pierre Nora opposes history and memory, yet Sturken counters that "Nora's concept of memory is highly nostalgic," and she rather "posit[s] cultural memory and history as entangled" (Sturken 3-5).

2 Similar metaphoric uses of the word "hack" appear in Jay David Bolter and Richard Grusin's work, while online "lifehacker" blogs sometimes also operate through the concept of hacking into the flow of power to redirect and distribute it, and sometimes suggest "hacking" as rethinking components of a concept using the resources at hand-for example, "hacking" pizza by using ramen instead of dough.

${ }^{3}$ Further background on The Yes Men's projects can be found in an interview with Andrew Denton of Enough Rope at www.abc.net.au/tv/enoughrope/transcripts/s1404748.htm.

${ }^{4}$ While the three poets discussed here are Black, their counternarrative hacks do not function as racially specific so much as in non-dominant ways.

${ }^{5}$ Recalling Havelock's modular understanding of Homer, which I discuss later.

${ }^{6}$ These metaphors of recycling and remix also call up the "gift economy."

${ }^{7}$ In the perpetual search for illustrations of the principle of invisible made visible, my current favorite example is Timo Arnall, Jørn Knutsen and Einar Sneve Martinussen's "Immaterials" projects, such as "Light painting WiFi," which "explores the invisible terrain of WiFi networks in urban spaces by light painting 
signal strength in long-exposure photographs." yourban.no/2011/02/22/immaterialslight-painting-wifi/.

${ }^{8}$ The metaphor comes from DuPlessis' commentary on Jean Rhys' Wide Sargasso Sea: "By a maneuver of encirclement (entering the story before) and leverage (prying the story open), Rhys ruptures Jane Eyre" (DuPlessis 46).

${ }^{9}$ She continues this recuperative unghosting and text-image exploration in her next book, Citizen (2014), which moves between racial violence and racist microaggressions (notably employing the second-person perspective more than the first).

${ }^{10}$ Connerton notes that images increase memory as well, since then the concrete item has been encoded twice (as verbal and as image) (Connerton 27). Perhaps this is why Benjamin argued that "History decays into images, not stories" (Schwartz). Perhaps the images would be better named "icons," gesturing toward DuPlessis' trove of myth.

${ }^{11}$ On her blog, Rankine makes concerted effort to discuss race and writing openly. At the 2011 AWP conference, Rankine shared her exchange with Tony Hoagland about a poem he described as "for white people" (www.poetryfoundation.org/harriet/2011/02/tony-hoaglands-poem-on-race-heatsthings-up-at-awp/). After issuing an "Open Letter" for thoughts about the intersections of writing and race, Rankine posted the responses:

www.newmediapoets.com/claudia_rankine/open/open.html

12 Static TV screens also appear throughout the text as separators. Within the static, the ghost image of George W. Bush's face is barely visible.

${ }^{13}$ Hayles takes this term from W.J.T. Mitchell, though she is disturbed that he remains unwilling to pursue the further implications for media theory (Hayles Machines 43).

${ }^{14}$ Other such textimages list drug companies, or announce "For Sale" and "Support Our Troops!" back to back (Rankine 114-116).

${ }^{15}$ I do not know whether Eady intentionally reflects the famous character Zero of Elmer Rice's The Adding Machine, but regardless the name has a similar effect here. Mr. Zero is an everyman just as he is a no man. In life he has no political power; as an image wielded, he unmakes or unmasks the world.

${ }^{16}$ A stanza in the poem cycle that does not appear in the play echoes Claudia's childhood queries of whether TV actors are dead: "Not the dead actor,Historically speaking,/but the ghost/Of the scripts, the bumbling fake/Of an acrobat, the lowitched anger/Someone mistook for stupid." (Rankine 6, Eady poems 32)

17 Another productive comparison might be Diana Taylor's Archive and the Repertoire: Performing Cultural Memory in the Americas, which explores the embodiment of cultural memory and the choices made in transmission, particularly in transcultural encounters.

18 This wrenching tragedy not only demarcates the inherent inhumanity and dehumanizing of the slave trade, its second hearing struck a blow for abolition, 
thanks in part to the publicizing efforts of Olaudah Equiano and Granville Sharp, as well as J.M.W. Turner's painting The Slave Ship, which appears on the last two pages of Rankine's Citizen. For further details, see The Zong: A Massacre, the Law and the End of Slavery by James Walvin (2011).

${ }^{19}$ The idea of "resistant mourning" comes from the work of Jahan Ramazani and R. Clifton Spargo, who eloquently state the case for elegy as activist work.

${ }^{20}$ I have tried to preserve where possible some of Philip's material spacing, but in order to see the actual poems, readers must go to the original.

${ }^{21}$ Other examples of this multidirectionality can be found throughout "Os," notably pages 7, 20, and 31 .

${ }^{22}$ In fact, after worrying about "how to read" the poems aloud, Philip reads even the final, most linguistically broken section as if written in complete words and phrases. Her reading choices can be heard at www.youtube.com/watch? $\mathrm{v}=$ my4eE4denus\&feature=related.

${ }^{23}$ One of the epigraphs to "Ferrum" comes from Ezekiel 37:7-10: "There was a noise and behold, a shaking... and the bones came together. bone to his bone...the sinews and flesh came upon them... and the skin covered them above...and the breath came into them... and they lived, and stood upon their feet" (Philip 126). Philip takes this conjuring/reanimation so seriously, she sought "spiritual permission" to write the poems (Philip xii).

${ }^{24}$ Rankine also loves the old tricks of shifting meaning through syntax: "people die no matter what you dream; or no matter what, you dream —-" (Rankine 121).

${ }^{25}$ Erik Ehn's examples of storytelling in the Rwandan genocide trials demonstrates the real-world need for artful hacks that conjure the lost from the dataset. www.howlround.com/2011/03/27/about-trauma-part-ii-erik-ehn/

\section{Works Cited}

Bolter, Jay David and Richard Grusin. Remediation: Understanding New Media. MIT Press, 2000.

Connerton, Paul. How Societies Remember. Cambridge University Press, 1989.

DuPlessis, Rachel Blau. "'Perceiving the other-side of everything': Tactics of a Revisionary Mythopoesis," Writing Beyond the Ending: Narrative Strategies of Twentieth-Century Women Writers. Indiana University Press, 1985.

Eady, Cornelius. Brutal Imagination. Playwright's manuscript, January 9, 2002, Text from the Vineyard Theatre production, December 2001-February 2002.

Eady, Cornelius. Brutal Imagination: Poems. Penguin Putnam Inc, 2001.

Flescher, Jennifer and Robert N. Caspar. "Interview with Claudia Rankine." jubilat, vol. 2007, University of Massachusetts, poems.com/special_features/prose/essay_rankine.php.

Havelock, Eric A. Preface to Plato. Belknap Press of Harvard University Press, 1963.

Hayles, N. Katherine. "Narrative and Database: Natural Symbionts." PMLA, vol. 
122, no. 5, October 2007, pp. 1603-1608, www.jstor.org/stable/25501808.

Hayles, N. Katherine. "Lexicon Linkmap," Writing Machines: Web Supplement," mitpress.mit.edu/sites/default/files/titles/content/mediawork/titles/writing/sup/sup _index.html. (Web supplement to Writing Machines.)

Hayles, N. Katherine. Writing Machines. The MIT Press, 2002.

Kochnar-Lindgren, Gray. Philosophy Art, and the Specters of Jacques Derrida. Cambria Press, 2011.

Mullen, Harryette. Recyclopedia. Graywolf Press, 2006.

Philip, M. NourbeSe. Zong! Wesleyan University Press, 2008.

Raley, Rita. Tactical Media. University of Minnesota Press, 2009.

Rankine, Claudia. Don't Let Me Be Lonely: An American Lyric. Gray Wolf Press, 2004.

Retallack, Joan. The Poethical Wager. University of California Press, 2003.

Rich, Adrienne. "Poetry and the Forgotten Future." A Human Eye: Essays on Art and Society, 1997-2008. W.W. Norton \& Co, 2009, pp. 123-146.

Schwartz, Vanessa R. "Walter Benjamin for Historians." The American Historical Review, vol. 106, no. 5, 2001, 50 pars, doi: doi.org/10.1086/ahr/106.5.1721.

Sturken, Marita. Tangled Memories: The Vietnam War, the AIDS Epidemic, and the Politics of Remembering. University of California Press, 1997.

Wark, McKenzie. A Hacker Manifesto. Harvard University Press, 2004. 